\title{
Stable isotopes reveal a consistent consumer-diet relationship across hundreds of kilometres
}

\author{
Mathew A. Vanderklift ${ }^{1, *}$, Thomas Wernberg ${ }^{2,3}$ \\ ${ }^{1}$ CSIRO Marine and Atmospheric Research, Private Bag 5, Wembley, WA 6913, Australia \\ ${ }^{2}$ Centre for Marine Ecosystems Research, Edith Cowan University, 100 Joondalup Dve, Joondalup, WA 6027, Australia \\ ${ }^{3}$ School of Plant Biology, University of Western Australia, 35 Stirling Hwy, Crawley, WA 6009, Australia
}

\begin{abstract}
Characterising geographical variation in trophic interactions is an important step towards understanding the consequences of changes in food webs. We characterised geographical variation across $\sim 1000 \mathrm{~km}$ in stable isotope values $\left(\delta^{15} \mathrm{~N}\right.$ and $\left.\delta^{13} \mathrm{C}\right)$ of the widely distributed sea urchin Heliocidaris erythrogramma and macroalgae that are its potential food. Variation in $\delta^{15} \mathrm{~N}$ of $H$. erythrogramma and macroalgae was typically greatest among locations separated by hundreds of $\mathrm{km}$, while variation in $\delta^{13} \mathrm{C}$ was typically greatest among reefs separated by a few $\mathrm{km}$. Geographical variation in $\delta^{15} \mathrm{~N}$ and $\delta^{13} \mathrm{C}$ of $H$. erythrogramma was well-explained by variation in $\delta^{15} \mathrm{~N}$ and $\delta^{13} \mathrm{C}$ of the kelp Ecklonia radiata. The slope and intercept of regressions of stable isotope ratios of $H$. erythrogramma on kelp were within the range predicted if the sea urchin's diet was exclusively kelp. These results are consistent with high reliance on a single diet across hundreds of $\mathrm{km}$, revealing that $H$. erythrogramma likely relies predominantly on a single food source, viz. E. radiata, across southwestern Australia.
\end{abstract}

KEY WORDS: Herbivory $\cdot$ Kelp $\cdot$ Niche width $\cdot$ Sea urchin $\cdot$ Trophic interactions Resale or republication not permitted without written consent of the publisher

\section{INTRODUCTION}

Predicting the outcomes of changes in the context of trophic interactions (e.g. new sources of nutrients or loss of key species) is a challenge to ecologists, who have yet to construct a reliable framework for predicting those consequences. Understanding geographical variation in trophic interactions is critical for generating insights into those consequences. However, ecologists still lack understanding of patterns and causes of geographical variations in the influence of consumers on their prey (interaction strength: e.g. Menge et al. 2004, Pennings \& Silliman 2005), and in the diets of consumers (e.g. Cabana \& Rasmussen 1996, Roth et al. 2007).

Geographical variation in diet occurs across a variety of gradients. For example, latitudinal gradients in trophic niche width (i.e. the diversity of prey consumed) may exist, although the direction and underlying mechanisms remain poorly understood (e.g. Clavero et al. 2003, Vázquez \& Stevens 2004). At smaller scales, diet can change among habitats or along environmental gradients (e.g. Paetzold et al. 2008, Waddington et al. 2008). Determining the spatial scales across which diets vary will be important for understanding the situations in which food webs vary, or remain consistent, across space.

Stable isotope analysis is a tool that can be used to resolve questions about geographical patterns in food webs. One way of using stable isotopes to investigate geographical variation in food webs is to use mixing models to reconstruct diets and determine trophic pathways at different places (Phillips \& Gregg 2001, Jackson et al. 2009; see example in Dang et al. 2009). However, even a modest number of potential diets (a situation typical in field studies), can lead to ambiguous conclusions if diets do not have distinct stable isotope ratios. This issue is not resolved by repeating mixing models for different places, as each will give a range of possible solutions with associated uncertainty. 
However, ecologists can also take advantage of geographical variation, for example by matching spatial patterns in consumers with those of potential diets (e.g. Melville \& Connolly 2003). For example, if spatial patterns in $\delta^{13} \mathrm{C}$ of a consumer are highly correlated with $\delta^{13} \mathrm{C}$ of only one potential diet, that would be evidence consistent with reliance on that diet. If spatial patterns in $\delta^{15} \mathrm{~N}$ of a consumer and diet are also correlated, this would be an indication of consistent trophic level, and would be further evidence consistent with this conclusion. However, this approach has a potential pitfall, as it relies on patterns of association that could potentially occur due to spatial autocorrelation (e.g. if spatial patterns in consumer and putative diet are each determined by an additional unmeasured influence, such as a gradient in $\delta^{15} \mathrm{~N}$ caused by a nitrogen source that influences all primary producers).

One way to identify when spatial autocorrelation might be present is partial regression analysis (Borcard et al. 1992, Legendre 1993). This approach allows identification of spurious correlations by partitioning variation that can be attributed to spatial structure from those due to other factors (see detailed discussion in Legendre \& Legendre 1998), and is often used as a way to identify likely environmental influences on geographical variations in abundance.

An additional test of the plausibility of the consumerdiet relationship using stable isotope ratios would be to test 2 predictions about the nature of the regression of consumer ratios on diet ratios. First, if a consumer relies on a single diet, the slope of the regression should be 1 . Second, because the stable isotope ratios of a consumer's tissues usually differ from those of its diet in a relatively predictable way, the intercept of the regression should be equivalent to the difference expected if the consumer was relying on that diet (i.e. the consumer-diet discrimination).

Our aims were to characterise geographical variation in stable isotope ratios of a consumer (the purple sea urchin Heliocidaris erythrogramma) and its potential diets (macroalgae), to explore how geographical variation might influence the outcomes of mixing models, and to evaluate the utility of partial regression analysis, coupled with tests of predictions about regressions, to identify likely diets. Understanding geographical variation in the diet of $H$. erythrogramma is useful because its diet has profound implications for the influence it exerts on rocky reef ecosystems. $H$. erythrogramma exerts an especially strong influence on rocky reefs in some areas of eastern Australia, where it can denude kelp-dominated ecosystems (Valentine \& Johnson 2005, Wright et al. 2005), but in southern and western Australia, it generally exerts a minor influence (Connell \& Irving 2008).

\section{MATERIALS AND METHODS}

Study area. Our study took place at 4 locations on the western coast of Australia, encompassing a geographical extent of $\sim 1000 \mathrm{~km}$ : Hamelin Bay $\left(34^{\circ} \mathrm{S}\right)$, Marmion Lagoon $\left(32^{\circ} \mathrm{S}\right)$, Jurien Bay $\left(30^{\circ} \mathrm{S}\right)$ and Kalbarri $\left(28^{\circ} \mathrm{S}\right)$. The nearshore environment along this coast is characterised by rocky reefs that host diverse assemblages of macroalgae. The small kelp Ecklonia radiata typically dominates the biomass of macroalgae on these reefs, but species richness is generally very high ( $>10-20$ species $0.25 \mathrm{~m}^{-2}$ ), and several species of fucalean algae (e.g. Scytothalia doryocarpa, Sargassum spp.) also attain high biomass in small patches (see Wernberg et al. 2003 and Smale et al. 2010 for details on assemblage structure). We collected 1 species of sea urchin (Heliocidaris erythrogramma, $\mathrm{n}=3$ ) and 3 species of algae (E. radiata, Ulva lactuca and Rhodymenia sonderi, $\mathrm{n}=3$ of each) at each of 3 reefs separated by $>1 \mathrm{~km}$ within each of the 4 locations (hereafter we use genus names only for simplicity). Ecklonia (kelp) and Rhodymenia (foliose red alga) were included because they are likely to contribute to the diet of Heliocidaris on the west coast of Australia (Vanderklift et al. 2006); Ulva (green alga) is likely to be a minor contributor to diet, but is present in small quantities in gut contents. At all reefs, Rhodymenia and Ulva were collected from open patches interspersed among the Ecklonia canopy. Only Ecklonia was found at Kalbarri. The study was done in the austral summer between December 2005 and January 2006.

Stable isotope analyses. Sea urchins and algae were collected by hand, kept on ice for up to $6 \mathrm{~h}$, and then frozen. In the laboratory, sea urchins and algae were thawed and tissue prepared for stable isotope analysis. For algae, sections of clean (i.e. without epibionts) tissue were removed from the thallus (entire thallus for Ulva and Rhodymenia, laterals for Ecklonia). For sea urchins, muscle tissue was dissected from the Aristotle's lantern. Tissue samples were rinsed with deionised water and dried in an oven at $60^{\circ} \mathrm{C}$. After drying, samples were ground using a ball mill and then stored in microcentrifuge tubes. $\delta^{15} \mathrm{~N}$ and $\delta^{13} \mathrm{C}$ were measured by continuous-flow isotope ratio mass spectrometry using a Europa Scientific ANCA-NT 20-20 isotope ratio mass spectrometer. The analytical precision derived from repeated measurements of internal standards (which had been previously calibrated against International Atomic Energy Agency or National Institute of Standards and Technology standards) was maximum $\pm 0.12(\mathrm{SD})$ for $\delta^{15} \mathrm{~N}$ and \pm 0.10 for $\delta^{13} \mathrm{C}$.

Statistical analyses. Geographical patterns in $\delta^{15} \mathrm{~N}$ and $\delta^{13} \mathrm{C}$ of algae and invertebrates were analysed using nested analysis of variance, with the factors Location ( $\mathrm{n}=4$ for Ecklonia, $\mathrm{n}=3$ for other taxa) and 
Reef ( $\mathrm{n}=3$, random and nested within each location). In 2 cases, there were missing values and so the degrees of freedom were adjusted.

Because we were particularly interested in the relative contribution of the 2 spatial scales (i.e. Location and Reef) to variation in stable isotope ratios, we calculated variance components and then calculated magnitudes of effects $\left(\omega^{2}\right)$ as the variance component for each factor divided by the sum of all variance components (Winer et al. 1991). When there were negative variance components, we followed the 'pool-the-minimumviolator' method outlined by Graham \& Edwards (2001) to set the negative variance components to 0 .

To test whether geographical variation in $\delta^{15} \mathrm{~N}$ and $\delta^{13} \mathrm{C}$ of Heliocidaris followed geographical variation of one or more algae, we used partial regression analysis (Legendre 1993), using mean $\delta^{15} \mathrm{~N}$ and $\delta^{13} \mathrm{C}$ per site. We partitioned variation in $\delta^{15} \mathrm{~N}$ and $\delta^{13} \mathrm{C}$ of Heliocidaris into (a) variation explained by stable isotope ratios of algae independent of a model of spatial structure (see below for details of the model), (b) variation shared by algae and the spatial model, (c) variation explained by the spatial model but not shared by algae, and (d) unexplained variation (i.e. not explained by either algae or the spatial model); for a detailed explanation of the method see Legendre \& Legendre (1998). Prior to partial regression analysis, we used stepwise regression to select only the subset of algae that most parsimoniously matched Heliocidaris, using Akaike's Information Criterion (AIC) as the statistic for model selection.

To model spatial structure, we first compared a simple linear model based on latitude $(x)$ and longitude $(y)$ of the reefs with a second order polynomial model based on these coordinates (Legendre \& Fortin 1989), in the form $z=x+y+x^{2}+x y+y^{2}$. The polynomial model allows identification of not only spatial patterns related to linear gradients (e.g. latitude), but also of more complex spatial patterns (e.g. patches), should they exist (Borcard et al. 1992). We used AIC as the statistic for model selection, and in each case, the second order polynomial model was selected. All statistical analyses were performed using the $\mathrm{R}$ language and environment for statistical computing and graphics (R Development Core Team 2008). We also tested whether the slope of the regression of consumer stable isotope ratios on individual diet stable isotope ratios differed significantly from 1.

Mixing models. Mixing models were used to explore how the range of feasible contributions of the 3 macroalgae to the diet of Heliocidaris was influenced by geographic variation in stable isotope ratios. We used the Stable Isotope Analysis in R (siar) package (Parnell 2008). We conducted separate analyses for each of the reefs where at least 3 individual Heliocidaris were collected. Stable isotope ratios of the macroalgae were adjusted to account for consumer-diet discrimination using average values for marine invertebrates taken from Caut et al. (2009, for $\delta^{13} \mathrm{C}$ ) and Vanderklift \& Ponsard (2003, for $\left.\delta^{15} \mathrm{~N}\right)$.

\section{RESULTS}

\section{Patterns of spatial variation}

For each of the macroalgae, $\delta^{15} \mathrm{~N}$ varied significantly among locations ( $\mathrm{p}<0.05$, Table 1, Fig. 1), and this was the dominant source of variation (accounting for $>57 \%$ of variance in each case). In each case, Student-Newman-Keuls (SNK) tests revealed that $\delta^{15} \mathrm{~N}$ of macroalgae collected from Marmion Lagoon was significantly higher than that from all other sites (Fig. 1). In contrast, differences among reefs were not significant ( $p>0.09$ in each case), and contributed little to variation $\left(<13 \%\right.$ in each case). $\delta^{15} \mathrm{~N}$ of Heliocidaris mirrored these trends, with differences among locations being large ( $>42 \%$ of total variance) and significant ( $\mathrm{p}<$ $0.05)$; the highest $\delta^{15} \mathrm{~N}$ were yielded by individuals collected from Marmion Lagoon (Fig. 1).

In contrast, patterns of spatial variation in $\delta^{13} \mathrm{C}$ of the algae were less consistent (Table 2, Fig. 1). Variation in $\delta^{13} \mathrm{C}$ of Ecklonia and Ulva among locations was virtually non-existent (leading to negative variance compo-

Table 1. Results of analyses of variance of $\delta^{15} \mathrm{~N}$ for 3 species of macroalgae (Ecklonia radiata, Rhodymenia sonderi and Ulva lactuca) and the sea urchin Heliocidaris erythrogramma, testing for differences among locations and reefs. $\omega^{2}$ : magnitude of effects

\begin{tabular}{|lcccccr|}
\hline Source & df & MS & $F$ & $p$ & $\begin{array}{c}\text { Variance } \\
\text { component }\end{array}$ & $\omega^{2}$ \\
& & & & & & \\
\hline Ecklonia radiata & & & & & & \\
Location & 3 & 4.05 & 24.03 & $<0.001$ & 0.432 & 76.5 \\
Reef (Location) & 8 & 0.17 & 1.47 & 0.219 & 0.018 & 3.2 \\
Residual & 24 & 0.11 & & & 0.115 & 20.3 \\
Rhodymenia sonderi & & & & & \\
Location & 2 & 2.14 & 8.51 & 0.018 & 0.218 & 57.5 \\
Reef (Location) & 6 & 0.25 & 2.18 & 0.096 & 0.047 & 12.4 \\
Residual & $17^{\mathrm{a}}$ & 0.11 & & & 0.114 & 30.1 \\
Ulva lactuca & & & & & & \\
Location & 2 & 3.94 & 51.68 & $<0.001$ & 0.430 & 89.2 \\
Reef (Location) & 6 & 0.08 & 1.91 & 0.135 & 0.012 & 2.5 \\
Residual & 18 & 0.04 & & & 0.040 & 8.3 \\
Heliocidaris erythrogramma & & & & \\
Location & 2 & 4.55 & 5.54 & 0.043 & 0.414 & 42.8 \\
Reef (Location) & 6 & 0.82 & 1.95 & 0.127 & 0.133 & 13.7 \\
Residual & 18 & 0.42 & & & 0.421 & 43.5 \\
& & & & & & \\
adf reduced to account for missing replicate & & \\
\hline
\end{tabular}



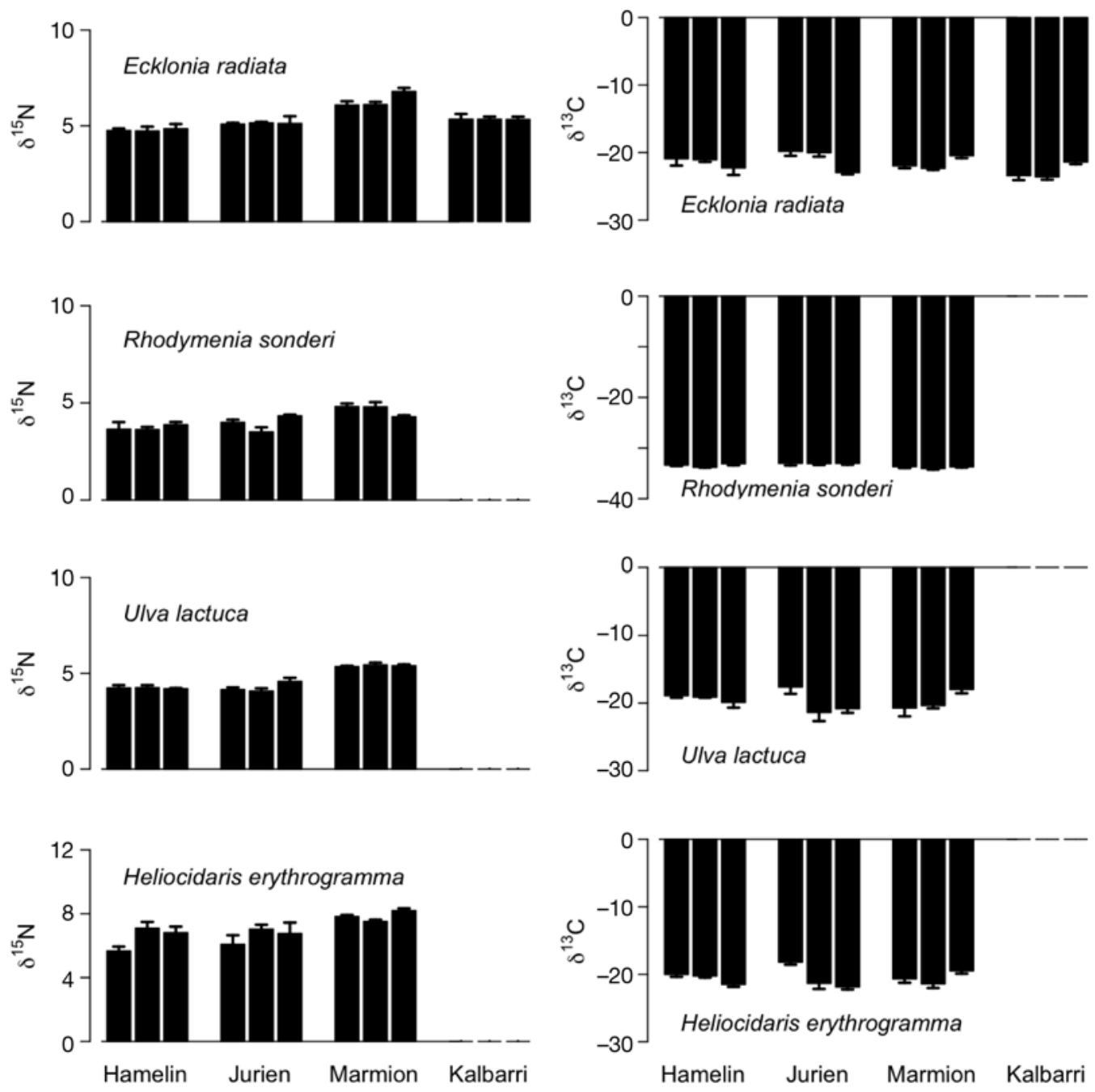

Fig. 1. $\delta^{15} \mathrm{~N}$ and $\delta^{13} \mathrm{C}$ of 3 species of macroalgae (Ecklonia radiata, Rhodymenia sonderi, Ulva lactuca) and 1 consumer (the sea urchin Heliocidaris erythrogramma) at 3 reefs at each of 4 locations in western Australia (mean $\pm \mathrm{SE}, \mathrm{n}=3$ )

nents), while variation among reefs was large (>37\%) and significant $(\mathrm{p}<0.02$ in each case). However, variation in $\delta^{13} \mathrm{C}$ of Rhodymenia among locations was large $(41.9 \%$ of variance) and significant $(p<0.03)$ while variation among reefs was minor $(1.1 \%)$. Variation among locations in $\delta^{13} \mathrm{C}$ of Heliocidaris was also small (leading to negative variance components) and not significant, but variation among reefs was large and significant $(63.9 \%, \mathrm{p}<0.001)$.

\section{Estimates of contribution to diet using mixing models}

The 1st to 99th percentile range of feasible contributions to the diet of Heliocidaris was large for each of the potential diets, indicating considerable uncertainty (Table 3). The highest feasible contributions at all sites were from Ecklonia (82 to $85 \%$ ) or Ulva (78 to $88 \%$ ), while Rhodymenia sonderi always yielded the lowest feasible contributions. For both Ecklonia and Ulva, the lower limit of feasible contributions was quite low (3 to $8 \%$ for Ecklonia and 2 to $7 \%$ for Ulva).

\section{Partitioning variation in stable isotope data with partial regression}

Patterns in $\delta^{15} \mathrm{~N}$ of Ecklonia alone more parsimoniously matched the patterns in $\delta^{15} \mathrm{~N}$ of Heliocidaris than any model including Ulva or Rhodymenia. $\delta^{15} \mathrm{~N}$ of Heliocidaris was strongly positively correlated with that of Ecklonia $\left(\mathrm{r}^{2}=0.67\right)$, and also strongly correlated with the spatial model based on geographical coordinates $\left(\mathrm{r}^{2}\right.$ adj $\left.=0.65\right)$. Variation partitioning indicated that 
Table 2. Results of analyses of variance of $\delta^{13} \mathrm{C}$ for 3 species of macroalgae (Ecklonia radiata, Rhodymenia sonderi and Ulva lactuca) and the sea urchin Heliocidaris erythrogramma, testing for differences among locations and reefs. $\omega^{2}$ : magnitude of effects

\begin{tabular}{|lcccccc|}
\hline Source & df & MS & $F$ & $\mathrm{p}$ & $\begin{array}{c}\text { Variance } \\
\text { component }\end{array}$ & $\omega^{2}$ \\
& & & & & & \\
\hline Ecklonia radiata & & & & & & \\
Location & 3 & 3.04 & 0.66 & 0.599 & -0.173 & 0 \\
Reef (Location) & 8 & 4.60 & 4.69 & 0.001 & 0.375 & 52.0 \\
Residual & 24 & 0.98 & & & 0.426 & 48.0 \\
Rhodymenia sonderi & & & & & \\
Location & 2 & 1.15 & 7.00 & 0.027 & 0.114 & 41.9 \\
Reef (Location) & 6 & 0.16 & 1.05 & 0.428 & 0.003 & 1.1 \\
Residual & 17 & 0.15 & & & 0.155 & 57.0 \\
Ulva lactuca & & & & & & \\
Location & 2 & 0.94 & 0.14 & 0.870 & -0.635 & 0 \\
Reef (Location) & 6 & 6.66 & 3.58 & 0.016 & 0.440 & 37.7 \\
Residual & 18 & 1.86 & & & 4.165 & 62.3 \\
Heliocidaris erythrogramma & & & & \\
Location & 2 & 0.07 & 0.01 & 0.987 & -0.630 & 0 \\
Reef (Location) & 6 & 5.75 & 8.39 & $<0.001$ & 1.687 & 63.9 \\
Residual & 18 & 0.68 & & & 0.685 & 36.1 \\
adf reduced to account for missing replicate & & \\
& & & & & \\
\hline
\end{tabular}

Table 3. Range (1st to 99th percentiles) of feasible contributions by 3 macroalgae to the diet of the sea urchin Heliocidaris erythrogramma

\begin{tabular}{|c|c|c|c|c|c|c|c|}
\hline \multirow{2}{*}{ Location } & \multirow[t]{2}{*}{ Site } & \multicolumn{2}{|c|}{ Ecklonia } & \multicolumn{2}{|c|}{ Rhodymenia } & \multicolumn{2}{|c|}{ Ulva } \\
\hline & & $1 \%$ & $99 \%$ & $1 \%$ & $99 \%$ & $1 \%$ & $99 \%$ \\
\hline \multirow{3}{*}{$\begin{array}{l}\text { Hamelin } \\
\text { Bay }\end{array}$} & 1 & 0.03 & 0.82 & 0.00 & 0.47 & 0.06 & 0.85 \\
\hline & 2 & 0.03 & 0.85 & 0.00 & 0.47 & 0.05 & 0.85 \\
\hline & 3 & 0.03 & 0.83 & 0.00 & 0.48 & 0.05 & 0.83 \\
\hline \multirow{3}{*}{$\begin{array}{c}\text { Marmion } \\
\text { Lagoon }\end{array}$} & 1 & 0.03 & 0.85 & 0.00 & 0.50 & 0.05 & 0.85 \\
\hline & 2 & 0.03 & 0.85 & 0.00 & 0.49 & 0.05 & 0.84 \\
\hline & 3 & 0.05 & 0.84 & 0.00 & 0.40 & 0.07 & 0.83 \\
\hline Jurien & 1 & 0.03 & 0.83 & 0.00 & 0.48 & 0.07 & 0.88 \\
\hline \multirow{2}{*}{ Bay } & 2 & 0.08 & 0.84 & 0.01 & 0.43 & 0.02 & 0.78 \\
\hline & 3 & 0.03 & 0.84 & 0.00 & 0.49 & 0.06 & 0.84 \\
\hline
\end{tabular}

most of the variation in $\delta^{15} \mathrm{~N}$ of Heliocidaris $(54 \%$; Fig. 2a) was jointly accounted for by variation in $\delta^{15} \mathrm{~N}$ of Ecklonia and spatial pattern, likely due to spatiallystructured variation in $\delta^{15} \mathrm{~N}$ of Ecklonia, that is, patterns in $\delta^{15} \mathrm{~N}$ of Ecklonia that varied in a way explained by the spatial model (see Borcard et al. 1992). Relatively little $(9 \%)$ was accounted for by variation in $\delta^{15} \mathrm{~N}$ of Ecklonia that was not spatially structured. A small amount of variation was accounted for by spatial structure different from that exhibited by Ecklonia (12\%), indicating that spatial variation due to factors other than those explained by Ecklonia were an additional small influence.
An additional test of whether consumption of Ecklonia can account for patterns in $\delta^{15} \mathrm{~N}$ of Heliocidaris is whether the intercept and slope of the regression match the values predicted if Ecklonia was the main diet source. The intercept for the regression of $\delta^{15} \mathrm{~N}$ of Heliocidaris on $\delta^{15} \mathrm{~N}$ of Ecklonia (Fig. 3a) was $2.18( \pm 3.05,95 \% \mathrm{CI})$, a result very close to the mean $(2.0 \%)$ for ammonotelic organisms reported by Vanderklift \& Ponsard (2003; Fig. 3a) and to that yielded in controlled laboratory experiments $(2.2 \%$, Gates 2006$)$. However, there was considerable uncertainty (confidence intervals were very large) around the estimate. The slope of the regression was $0.89( \pm 0.56$, $95 \% \mathrm{CI}$ ), which was not significantly different from the predicted value of $1(p>0.66)$. Both results are consistent with the values predicted if Ecklonia was the main food source for Heliocidaris.

The combination of Ecklonia and Ulva most parsimoniously matched the patterns in $\delta^{13} \mathrm{C}$ of Heliocidaris. $\delta^{13} \mathrm{C}$ of each alga was positively correlated with that of Heliocidaris, both separately (Ecklonia, $\mathrm{r}^{2}=0.54 ;$ Ulva, $\mathrm{r}^{2}=0.79$ ) and together $\left(\mathrm{r}^{2}{ }_{\text {adj }}=0.85\right)$. Unlike $\delta^{15} \mathrm{~N}$, no variation in $\delta^{13} \mathrm{C}$ of Heliocidaris was accounted for by spatial structure, either uniquely or shared with $\delta^{13} \mathrm{C}$ of algae (Fig. 2b; negative variation is due to the presence of strong correlations between the algae and the spatial model, see Legendre \& Legendre 1998). A large proportion of variation was accounted for by non-spatial patterns in $\delta^{13} \mathrm{C}$ of the algae (Fig. 2b).

This result is consistent with reliance by Heliocidaris on both algae, but does not enable determination of whether 1 alga is consumed more. We therefore tested predictions about the expected slope and intercept of the regressions in an attempt to do so. The regression of $\delta^{13} \mathrm{C}$ of Heliocidaris on $\delta^{13} \mathrm{C}$ of Ecklonia in our data yielded an intercept of $-3.98( \pm 13.61,95 \% \mathrm{CI})$; the high variability around the estimate was heavily influenced by 1 reef at Jurien Bay (Cook's distance $>1$; Fig. 3b). All other reefs yielded $\delta^{13} \mathrm{C}$ within $0.8 \%$ of the expected value. The estimate of the intercept without this site was $3.32( \pm 5.21,95 \% \mathrm{CI})$. Mean $\delta^{13} \mathrm{C}$ discrimination of ammonotelic organisms in a recent review by Caut et al. (2009) was 0.48 but varied from -3.4 to 5.5. Regression of $\delta^{13} \mathrm{C}$ of Heliocidaris on $\delta^{13} \mathrm{C}$ of Ecklonia yielded a slope of $0.78( \pm 0.64,95 \% \mathrm{CI})$; a slope of $1.1( \pm 0.24,95 \% \mathrm{CI})$ was obtained with the outlier excluded. The regression of Heliocidaris on Ulva (Fig. 3c) yielded a slope of $0.79( \pm 0.37,95 \% \mathrm{CI})$ and an intercept of $-5.01( \pm 7.22,95 \% \mathrm{CI})$, with most reefs yielding values $>1 \%$ lower than the predicted value. 

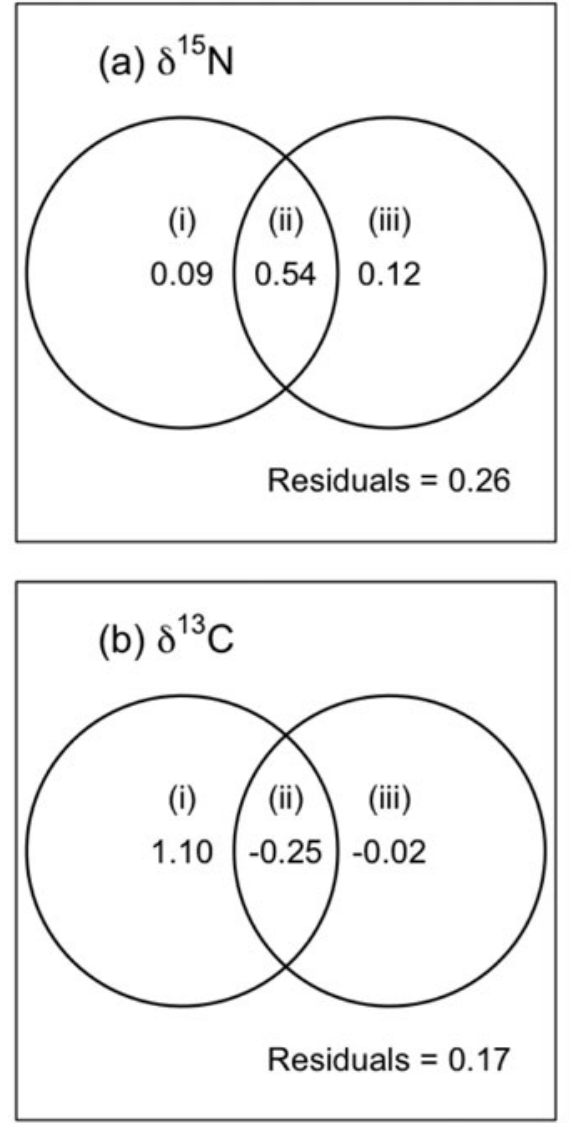

Fig. 2. Heliocidaris erythrogramma. Proportion of variation of (a) $\delta^{15} \mathrm{~N}$ and (b) $\delta^{13} \mathrm{C}$ of the sea urchin explained by stable isotope ratios of potential food algae, by a spatial model based on geographical coordinates, and by both combined. (i) Variation explained by stable isotope ratios of algae independent of the spatial model, (ii) variation shared by stable isotope ratios of algae and the spatial model, (iii) variation explained by the spatial model but not shared by algae

\section{DISCUSSION}

Spatial variation in $\delta^{15} \mathrm{~N}$ among locations (hundreds of $\mathrm{km}$ apart) was large and statistically significant for all taxa, while variation in $\delta^{13} \mathrm{C}$ among reefs (few $\mathrm{km}$ apart) was large and statistically significant for 3 of 4 taxa. $\delta^{15} \mathrm{~N}$ and $\delta^{13} \mathrm{C}$ of Heliocidaris muscle exhibited spatial patterns that closely matched those of Ecklonia, and the intercepts of the regressions were within the range predicted by laboratory studies.

\section{Spatial variation in $\delta^{15} \mathrm{~N}$ and $\delta^{13} \mathrm{C}$}

Spatial variation in $\delta^{15} \mathrm{~N}$ and $\delta^{13} \mathrm{C}$ allows some insights into the processes supporting the production of algal biomass, and thus ultimately the food webs of the rocky reefs. $\delta^{15} \mathrm{~N}$ of all algae showed significant vari-
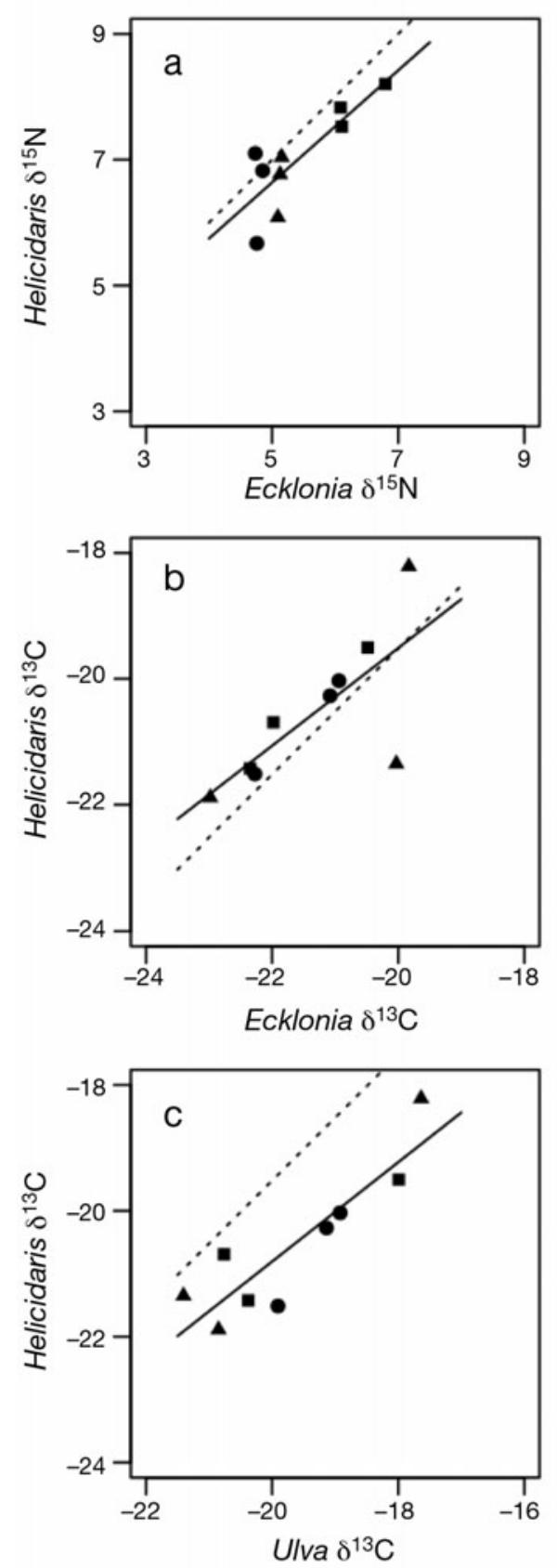

Fig. 3. Plots of stable isotope ratios of the sea urchin Heliocidaris erythrogramma versus stable isotope ratios of potential food sources: (a) $\delta^{15} \mathrm{~N}$ of Ecklonia radiata, (b) $\delta^{13} \mathrm{C}$ of E. radiata and (c) $\delta^{13} \mathrm{C}$ of Ulva lactuca. (घ) Site means from Marmion Lagoon, (₫) site means from Jurien Bay, $(\bullet)$ site means from Hamelin Bay. Solid line represents regression from the data, dotted line represents predicted regression for marine invertebrates from Vanderklift \& Ponsard (2003, for $\delta^{15} \mathrm{~N}$ ) or Caut et al. $\left(2009\right.$, for $\left.\delta^{13} \mathrm{C}\right)$

ability among locations separated by hundreds of $\mathrm{km}$, largely due to elevated $\delta^{15} \mathrm{~N}$ in algae collected from Marmion Lagoon. Marmion Lagoon is situated adjacent to the northern suburbs of Perth, a city with a pop- 
ulation of $\sim 1.5$ million, and the only large city on the west coast of Australia. The elevated $\delta^{15} \mathrm{~N}$ in Marmion Lagoon is thus likely a result of anthropogenic sources of nutrients. Gartner et al. (2002) found that a wastewater outfall $\sim 5 \mathrm{~km}$ north of our study area was a probable source of elevated $\delta^{15} \mathrm{~N}$ for up to $2 \mathrm{~km}$, and near the outfall recorded $\delta^{15} \mathrm{~N}$ approximately twice as high as the values we recorded. Our results suggest that the influence of anthropogenic sources of nutrients is reflected in algae throughout Marmion Lagoon. $\delta^{15} \mathrm{~N}$ of algae showed little variation among reefs separated by hundreds of metres, suggesting that at this spatial scale the sources of nitrogen are broadly consistent.

In contrast, spatial patterns in $\delta^{13} \mathrm{C}$ of algae suggested that local (among reefs, distances of 1 to a few $\mathrm{km}$ ) influences were important for Ecklonia and Ulva, but large-scale influences (among locations, distances of hundreds of $\mathrm{km}$ ) were important for Rhodymenia. Local variation in $\delta^{13} \mathrm{C}$ is expected where environmental influences such as light availability and water motion influence rates of photosynthesis, but it is unclear how different primary producers will respond to this variation. The observation that the different algae did not show spatially consistent patterns suggests that differences among species in use of various sources of organic and inorganic carbon, and/or physiological mechanisms for carbon capture and storage (Raven et al. 2002), are an important influence on spatial patterns. If this is general among primary producers it could help resolve trophic interactions in cases where stable isotope ratios are similar, and differentiation among food sources is ambiguous.

\section{Using spatial patterns to infer diet}

Mixing models (siar) performed for each site yielded maximum contributions ranging from 82 to $85 \%$ for Ecklonia and 78 to $88 \%$ for Ulva. The wide range of feasible contributions and the overlapping estimates illustrate that uncertainty in interpreting results from a single place is not necessarily alleviated by repeating analyses for other places (see also Melville \& Connolly 2003). Combining partial regression analyses with tests of predictions about the regressions provided a powerful way of identifying the reliance of Heliocidaris on a single diet that was not possible using mixing models. By using the information contained in the spatial variation, the partial regression approach helped identify that Ecklonia is likely to be the main component of the diet of Heliocidaris over hundreds of $\mathrm{km}$. Several lines of evidence from the regression analyses point to extensive reliance by Heliocidaris on Ecklonia. First, only Ecklonia was included in the most parsimonious model explaining variation in $\delta^{15} \mathrm{~N}$. Second, although both
Ecklonia and Ulva were included in the most parsimonious model explaining variation in $\delta^{13} \mathrm{C}$, Ecklonia provided a much better fit to the $\delta^{13} \mathrm{C}$ of Heliocidaris.

The methods are extensible to multivariate situations (Borcard et al. 1992), and so could readily accommodate multiple elements. Mixing models remain a key tool for interpreting stable isotope data, but analysis of spatial patterns could be used to inform these models to reduce uncertainty.

\section{Reliance on kelp Ecklonia radiata}

The apparently widespread reliance of Heliocidaris on a single diet is inconsistent with the view that sea urchins are generalist consumers that eat a wide range of prey (Lawrence 1975, Andrew 1989). This view has perhaps been shaped largely by the flexible diets of some of the more commonly studied taxa, such as species within the families Strongylocentrotidae and Diadematidae. Indeed, the flexible diet of sea urchins within these families often leads to strong effects on their ecosystems as they can consume all erect algae over vast areas (e.g. Mann 1982). However, studies of food choice by sea urchins often indicate that they strongly select certain food under laboratory conditions, but that those choices are not reflected in the wild (Schiel 1982). This observation likely reflects a trade-off between maximising consumption of food that best enhances growth and reproduction, and reducing the risk of mortality and the energetic costs of searching (Schoener 1971).

Our conclusions are based on surveys of 3 potential algae diets. Numerous other species of algae are present on the reefs we surveyed, and we cannot rule out the possibility that some of them might also contribute to the diet of Heliocidaris. However, our choices were guided by prior knowledge of the types of algae that typically dominate the gut contents of Heliocidaris (Vanderklift et al. 2006), so the conclusions are probably quite robust. The apparently narrow diet of Heliocidaris across the hundreds of $\mathrm{km}$ our study encompassed can be reconciled by the observation that in western Australia it tends to feed on drift algae (Vanderklift \& Kendrick 2005, Vanderklift \& Wernberg 2008), and drift algae are dominated by Ecklonia, even where it is not the dominant alga on the reef (Wernberg et al. 2006). Further, even where a variety of drift algae and seagrasses are available, Heliocidaris selectively retains Ecklonia over other species (Vanderklift \& Kendrick 2005, Vanderklift \& Wernberg 2008). The passive 'drift-feeding' behaviour of Heliocidaris is not unusual among sea urchins, and might be an optimal mode of foraging in an environment where the threat of being eaten by predators or dislodged by waves is 
significant. Although Heliocidaris that inhabit inshore reefs are able to consume drift Ecklonia originating offshore (Vanderklift \& Wernberg 2008), our surveys during this study were conducted on offshore reefs, where Heliocidaris must rely more on locally-generated drift.

\section{Narrow trophic niche occupied by a 'generalist' herbivore}

Heliocidaris on the eastern coast of Australia apparently exhibits a wider range of feeding behaviour, with evidence that it feeds on drift algae and that it adopts a mobile grazing behaviour (Valentine \& Johnson 2005, Wright et al. 2005). This latter behaviour is associated with extensive defoliation of kelp forests. The narrow diet we observed in western Australia might therefore reflect a 'realised niche' within a broader 'fundamental niche'. Other species of sea urchins elsewhere are able to switch between drift-feeding and grazing behaviours depending on the availability of drift algae (Harrold \& Reed 1985).

By taking a geographic perspective, we have shown that a consumer, the sea urchin Heliocidaris erythrogramma, likely relies on a consistent food source across hundreds of $\mathrm{km}$ of its distribution on the west coast of Australia. The finding that Heliocidaris relies extensively on Ecklonia adds to growing evidence of the disproportionate importance of Ecklonia in supporting food webs (Vanderklift \& Wernberg 2008, Crawley et al. 2009). The distribution and abundance of kelp elsewhere in Australia has been reduced by multiple impacts, including low water quality, invasive species and overgrazing by herbivores (Connell et al. 2008, Ling 2008). The broad trophic importance of kelp on the west coast of Australia and its apparent sensitivity to impacts imply that it will be important for conservation efforts to focus on minimising threats to kelp.

Acknowledgements. This research was partially supported by an ARC Discovery grant (DP0555929) to T.W. The manuscript was improved by thoughtful comments from P. Frouin, R. Inger and P. Lavery. The research described in this paper complies with the laws of Australia.

\section{LITERATURE CITED}

Andrew NL (1989) Contrasting ecological implications of food limitation in sea urchins and herbivorous gastropods. Mar Ecol Prog Ser 51:189-193

Borcard D, Legendre P, Drapeau P (1992) Partialling out the spatial component of ecological variation. Ecology 73: 1045-1055

Cabana G, Rasmussen JB (1996) Comparison of aquatic food chains using nitrogen isotopes. Proc Natl Acad Sci USA 93:10844-10847
Caut S, Angulo E, Courchamp F (2009) Variation in discrimination factors $\left(\delta^{15} \mathrm{~N}\right.$ and $\left.\delta^{13} \mathrm{C}\right)$ : the effect of diet isotopic values and applications for diet reconstruction. J Appl Ecol 46:443-453

Clavero M, Prenda J, Delibes M (2003) Trophic diversity of the otter (Lutra lutra L.) in temperate and Mediterranean freshwater habitats. J Biogeogr 30:761-769

Connell SD, Irving AD (2008) Integrating ecology with biogeography using landscape characteristics: a case study of subtidal habitat across continental Australia. J Biogeogr 35:1608-1621

Connell SD, Russell BD, Turner DJ, Shepherd SA and others (2008) Recovering a lost baseline: missing kelp forests from a metropolitan coast. Mar Ecol Prog Ser 360:63-72

Crawley KR, Hyndes GA, Vanderklift MA, Revill AT, Nichols PD (2009) Allochthonous brown algae are the primary food source for consumers in a temperate, coastal environment. Mar Ecol Prog Ser 376:33-44

Dang C, Sauriau PG, Savoye N, Caill-Milly N and others (2009) Determination of diet in Manila clams by spatial analysis of stable isotopes. Mar Ecol Prog Ser 387:167-177

Gartner A, Lavery P, Smit AJ (2002) Use of $\delta^{15} \mathrm{~N}$ signatures of different functional forms of macroalgae and filter-feeders to reveal temporal and spatial patterns in sewage dispersal. Mar Ecol Prog Ser 235:63-73

Gates EN (2006) Determining carbon and nitrogen stable isotope discrimination for marine consumers. Honours thesis, Edith Cowan University, Perth

Graham MH, Edwards MS (2001) Statistical significance versus fit: estimating the importance of individual factors in ecological analysis of variance. Oikos 93:505-513

> Harrold C, Reed DC (1985) Food availability, sea urchin grazing, and kelp forest community structure. Ecology 66: 1160-1169

Jackson AL, Inger R, Bearhop S, Parnell A (2009) Erroneous behaviour of MixSIR, a recently published Bayesian isotope mixing model: a discussion of Moore \& Semmens (2008). Ecol Lett 12:E1-E5

Lawrence JM (1975) On the relationship between marine plants and sea urchins. Oceanogr Mar Biol Annu Rev 13: 213-286

Legendre P (1993) Spatial autocorrelation: trouble or new paradigm? Ecology 74:1659-1673

Legendre P, Fortin MJ (1989) Spatial pattern and ecological analysis. Vegetatio 80:107-138

Legendre P, Legendre L (1998) Numerical ecology. Elsevier, Amsterdam

> Ling SD (2008) Range expansion of a habitat-modifying species leads to loss of taxonomic diversity: a new and impoverished reef state. Oecologia 156:883-894

Mann KH (1982) Kelp, sea urchins and predators: a review of strong interactions in rocky subtidal systems of eastern Canada, 1970-1980. Neth J Sea Res 16:414-423

> Melville AJ, Connolly RM (2003) Spatial analysis of stable isotope data to determine primary sources of nutrition for fish. Oecologia 136:499-507

> Menge BA, Blanchette C, Raimondi P, Freidenburg T and others (2004) Species interaction strength: testing model predictions along an upwelling gradient. Ecol Monogr 74: $663-684$

> Paetzold A, Lee M, Post DM (2008) Marine resource flows to terrestrial arthropod predators on a temperate island: the role of subsidies between systems of similar productivity. Oecologia 157:653-659

Parnell A (2008) siar: stable isotope analysis in R. R package version 3.2. http://cran.r-project.org/web/packages/siar/ index.html 
Pennings SC, Silliman BR (2005) Linking biogeography and community ecology: latitudinal variation in plant-herbivore interaction strength. Ecology 86:2310-2319

Phillips DL, Gregg JW (2001) Uncertainty in source partitioning using stable isotopes. Oecologia 127:171-179

R Development Core Team (2008) R: a language and environment for statistical computing. R Foundation for Statistical Computing, Vienna

Raven JA, Johnston AM, Kübler JE, Korb R and others (2002) Mechanistic interpretation of carbon isotope discrimination by marine macroalgae and seagrasses. Funct Plant Biol 29:355-378

Roth JD, Marshall JD, Murray DL, Nickerson DM, Steury TD (2007) Geographical gradients in diet affect population dynamics of Canada lynx. Ecology 88:2736-2743

Schiel DR (1982) Selective feeding by the echinoid, Evechinus chloroticus, and the removal of plants from subtidal algal stands in northern New Zealand. Oecologia 54:379-388

Schoener TW (1971) Theory of feeding strategies. Annu Rev Ecol Syst 2:369-404

Smale DA, Kendrick GA, Wernberg T (2010) Assemblage turnover and taxonomic sufficiency of subtidal macroalgae at multiple spatial scales. J Exp Mar Biol Ecol 384: 76-86

> Valentine JP, Johnson CR (2005) Persistence of sea urchin (Heliocidaris erythrogramma) barrens on the east coast of Tasmania: inhibition of macroalgal recovery in the absence of high densities of sea urchins. Bot Mar 48: 106-115

Vanderklift MA, Kendrick GA (2005) Contrasting influence of sea urchins on attached and drift macroalgae. Mar Ecol

Editorial responsibility: Otto Kinne,

Oldendorf/Luhe, Germany
Prog Ser 299:101-110

Vanderklift MA, Ponsard S (2003) Sources of variation in consumer-diet $\delta^{15} \mathrm{~N}$ enrichment: a meta-analysis. Oecologia 136:169-182

Vanderklift MA, Wernberg T (2008) Detached kelps from distant sources are a food subsidy for sea urchins. Oecologia 157:327-335

Vanderklift MA, Kendrick GA, Smit AJ (2006) Differences in trophic position among sympatric sea urchin species. Estuar Coast Shelf Sci 66:291-297

> Vázquez DP, Stevens RD (2004) The latitudinal gradient in niche breadth: concepts and evidence. Am Nat 164:E1-E19

Waddington KI, Bellchambers LM, Vanderklift MA, Walker DI (2008) Western rock lobsters (Panulirus cygnus) in Western Australian deep coastal ecosystems (35-60 m) are more carnivorous than those in shallow coastal ecosystems. Estuar Coast Shelf Sci 79:114-120

> Wernberg T, Kendrick GA, Phillips JC (2003) Regional differences in kelp-associated algal assemblages on temperate limestone reefs in south-western Australia. Divers Distrib 9:427-441

Wernberg T, Vanderklift MA, Lavery PS, How J (2006) Export of detached macroalgae from reefs to adjacent seagrass beds. Oecologia 147:692-701

Winer BJ, Brown DR, Michels KM (1991) Statistical principles in experimental design. McGraw-Hill, New York

> Wright JT, Dworjanyn SA, Rogers CN, Steinberg PD, Williamson JE, Poore AGB (2005) Density-dependent sea urchin grazing: differential removal of species, changes in community composition and alternative community states. Mar Ecol Prog Ser 298:143-156

Submitted: June 29, 2009; Accepted: January 8, 2010

Proofs received from author(s): March 4, 2010 